\title{
THE POWER OF IMAGES: THE BIBLE IN ART AND VISUAL REPRESENTATION IN SOUTH AFRICA ${ }^{1}$
}

\author{
Sakkie Cornelius \\ Department of Ancient Studies \\ Stellenbosch University
}

\begin{abstract}
Artists are not merely illustrators, but also interpreters of ancient texts such as the Bible. The works of South African artists such as Mbatha on biblical stories are well known, but the art of the Namibian Muafangejo should also be acknowledged. Examples from the book of Genesis in the medium of the linoprint are discussed and compared with other representations in art. The work of Mbatha and Muafangejo represent an African reading of the text.
\end{abstract}

\section{Introduction}

Our colleague and friend Yeshuah Gitay is well known for his contributions to the field of the rhetoric of the Hebrew Bible, but in a recent article on Job (2003) he also emphasised the way in which an ancient text can be read in contemporary South African society. Artists are also readers of ancient texts, as his wife Zefira has shown in articles devoted to Ruth (1993), the wife of Job (1995a) and queen Esther (1995b) in visual art. $^{2}$ In this article I want to reflect on the way in which South African artists are not mere illustrators of a text (in this case the Bible), but are interpreters.

The Bible, an ancient book, has played an important role in the art of the Judaic, Christian and Islamic world (Bocian 1989). The role of the Bible in Africa can be judged very negatively, as is evident in the following anecdote: "When the white man came to our country he had the Bible and we had the land. The white man said to us: 'Let us pray.' After the prayer, the white man had the land and we had the Bible" (West 2001: 30). On the other hand, the Bible has become an integral part of Africa and there are voices emphasising the role of Africans in creating and interpreting the Bible. ${ }^{3}$

Contextual interpretation of the Bible with regard to South Africa is nothing new but, with the exception of the work of Mbatha, very little has been written on the visual arts in South Africa reflecting interpretations of the Bible. ${ }^{4}$ In this article works of the artists Mbatha and Muafangejo will be discussed. The emphasis will be on motifs from the biblical book of Genesis.

1. An earlier version of this article was read as part of a graduate research colloquium in Tübingen (Germany) in 2003 (by invitation of Bernd Janowski). I want to thank Gerald West and Juliette Leeb-du Toit (University of KwaZulu-Natal), Michael Godby (University of Cape Town), Sandra Klopper and Lize van Robbroeck (University of Stellenbosch), and my doctoral student Pastor Mzonzima Gwala (Helderberg College, Somerset West) for discussing some of the issues with me, although I am solely responsible for what is written here. Unfortunately it was impossible to give illustrations of all the art works referred to, but references to printed versions are given.

2. As also shown in my article on representations of Gen 3 in art (Cornelius 1997).

3. Cf. West \& Dube (2001) and recently Adamo (2003) with bibliography.

4. West is busy with a project which involves collecting examples of biblical themes in Black South African art. 


\section{Azaria Mbatha ${ }^{5}$}

Azaria Mbatha was born in 1941 at Mabeka in KwaZulu Natal. Between 1963 and 1966 he studied at the Evangelical Lutheran Church Art and Craft Centre at Rorke's Drift (Hobbs \& Rankin 2003) under Peter Gowenius. In 1966 Mbatha was awarded a scholarship to study at the Konst Jack Art School in Stockholm and in 1967 he returned to teach at Rorke's Drift. Mbatha left South Africa in 1970 to complete his formal education, but remained in exile and settled in Sweden. He was the first African graphic artist whose work was included in the collection of the Museum of Modern Art in New York. Early on in his career Mbatha decided to concentrate on graphics, particularly linocuts in which he "seizes and refashions the left-to-right and top-to-bottom conventions of colonial text to tell an African story of struggle from a European brought book - the Bible" (West 1999: 103). ${ }^{6}$ These tableaux narrative scenes represent various biblical themes such as Creation, Noah's Ark, the Tower of Babylon, the Sermon on the Mount, the Crucifixion, Salome and the lives of biblical personae in the form of storyboards, e.g. of Cain and Abel, Joseph, Moses, Jonah, Jesus, the Apostles and St Paul). The influence of the Bible from Mbatha's schooldays and art training is clear. But he goes further and re-reads the Bible within his own context, ${ }^{7}$ reflecting an independent reading of the Bible, "re-membering" the Bible stories for the SA context, as so clearly shown by West (1999: 105).

Biblical personae are either black or white. In a scene depicting David beheading the giant Goliath (Addleson 1998: 58-59, 104, Cat. 20; Sundermeier 1977: 30-31), David and the Israelites are all black, Goliath and the Philistines are white (the oppressors). ${ }^{8}$ This work is a statement of resistance and a prediction of the vanquishing of white racism (Hobbs \& Rankin 2003: 173-174). But there is also a development in his work as far as "colour" is concerned (cf. Mbatha himself in Addleson 1998: 57ff.)

Gen 1-3 has always fascinated artists (Cornelius 1997; Von Erffa 1989: 36-248). In Mbatha's "Creation" of 1964 (Addleson 1998: 57, 104, Cat. 19; Eichel 1986: 71, \#82; Sundermeier 1977: 12-13) we see the white Creator, the black angels ${ }^{9}$ and the African animals with a bull in the centre. In Zulu culture the bull plays an important role and symbolises life. ${ }^{10}$ The creator is here presumably a type of uNkulunkulu, "the old old one", "the great one", a Semitic-like El-figure, Hebrew El-Elyon.

5. Cf. the entry in Turner (1996: Vol. 20: 910, also Vol. 29: 110-111 with Fig. 5). An autobiography is currently being edited and a catalogue raisonné of his work is in preparation. Cf. inter alia Addleson (1998), which contains important reflective essays. Selections of graphic works can also be found in Eichel (1986) and Sundermeier (1977).

6. The item under discussion is not a woodcut as in West (1999: 103 and 2001: 39), but a linocut as West has it in Addleson (1998: 82-88). A linocut is made by cutting into linoleum and not by using a wood block as a matrix. For the difference between the two media cf. Hobbs \& Rankin (2003: 208) and the relevant entries in Turner (1996).

7. On Mbatha's use of biblical themes cf. the excellent description by J Leeb-du Toit (in Addleson 1998: 36-49).

8. The soldier with the shield and spear looks like a typical Zulu impi warrior. This is indigenous SA art, but in early European art the Philistines were depicted as medieval knights.

9. To indicate that we are in Africa (Mbatha in Addleson 1998: 57).

10. Cf. Sundermeier (1977: 12)

11. In the 1959 Zulu Bible this is the translation of the Hebrew Elohim (Dr. Eric Hermanson and Pastor M. Gwala). 
Mbatha (Eichel 1986: 68, \#62; Sundermeier 1977: 14-15 = Fig. 1) shows Adam and Eve as black people in a work from 1968. Eve gives the forbidden fruit to Adam. There is no traditional serpent, but a being which is both animal and human, with a mask $^{12}$ and an arm reminiscent of a snake (Sundermeier 1977: 14). This is different to other renderings, where the snake is either a real snake or not an ordinary reptile (i.e. a snake with female head, a dragon, demon or devil - cf. Cornelius 1997: 225-226 and Von Erffa 1989: 171-176).

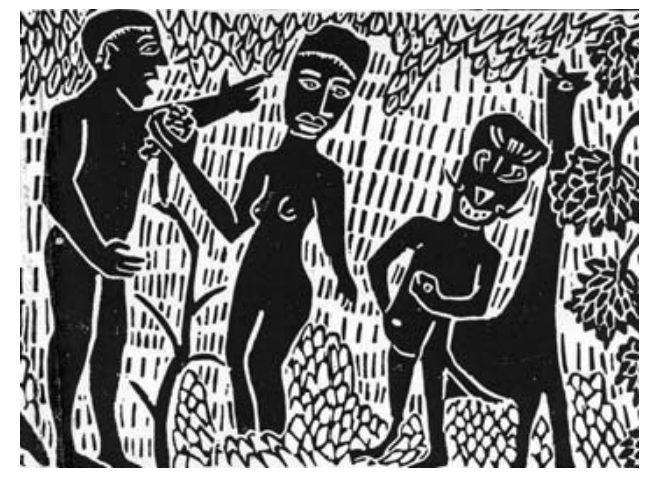

One of the most popular biblical scenes in art has always been the sacrifice of Isaac in Gen 22. ${ }^{13}$ Mbatha (Sundermeier 1977: 18-19 = Fig. 2) shows the ram in the thicket (v. 13). Isaac is on the altar and Abraham holds the knife. The angel is a traditional winged figure standing next to and pointing to Abraham, although the Hebrew text says that the angel of the Lord called from heaven (v. 11). ${ }^{14}$ The

Fig. 1 fire is in a big black African pot, an indigenous way to keep fire, as it would be impossible to carry the fire by hand as described in $\mathrm{v}$. $6{ }^{15}$ In art the fire is mostly carried in a dish (Von Erffa 1995: 174).

For the story of Joseph (Gen 37, 39-50), the Germans have their Joseph und seine Brüder by Thomas Mann (Golka 2002). Gerald West (Fig. 3) ${ }^{16}$ drew attention to the Joseph story in South African Black art through the

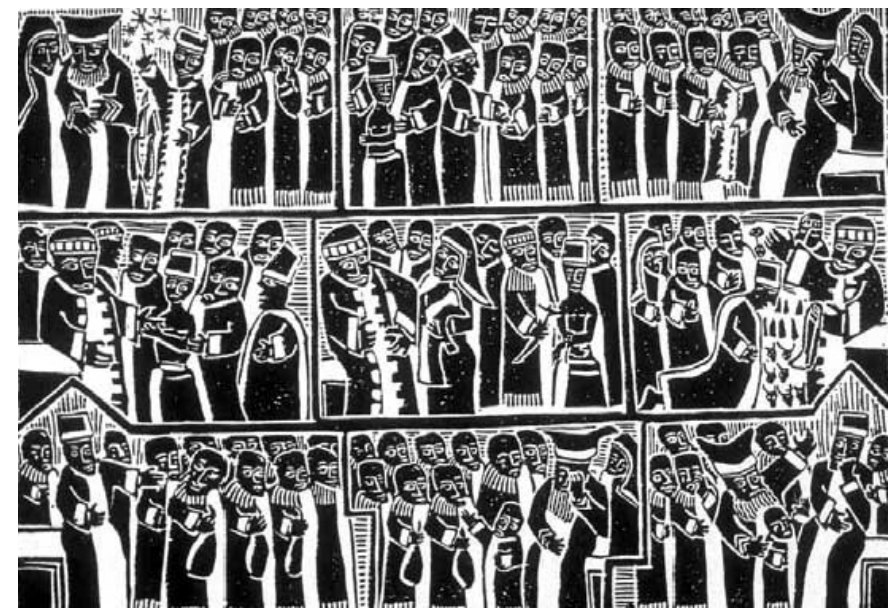

Fig. 3

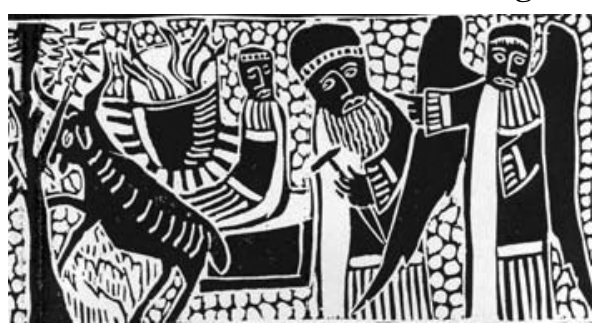

Fig. 2

12. The significance of this should not be exaggerated (e.g. as by Eichel 1986: 5) as masks do not play such an important role in Zulu culture, as Rankin and Hobbs (in Addleson 1998: 69) observe.

13. Cf. Von Erffa (1995: 145-191).

14. In other art works (like that of Rembrandt - cf. Von Rad 1976: 90) the angel literally grabs the arm of Abraham to stop him! (cf. Von Erffa 1995: 181-182).

15. Cf. Van Selms (1967: 22) who describes it as glowing embers in a ceramic dish.

16. Cf. West (in Addleson 1998: 82-88 with Cat. 39 and 1999: 101-105) on which the discussion is based. 
work of Mbatha. What is written here is therefore not original, but nevertheless included because of its importance to the whole theme.

Mbatha sets his story in Africa - which, after all, was where a great part of the story took place. He depicts the story with an emphasis on Africa and its concern with community. This concept is expressed by the isi-Xhosa words Umntu ngumntu ngabantu "A person is a person because of other people" or the concept of ubuntu ("collectiveness"). Joseph is not simply an individual, but his story is the story of a community. The greatest threat is not to his person, but to ubuntu.

In this contextual reading we meet the family in scene 1: Joseph the dreamer through whom the amadlozi ("ancestors") speak. In scene 2 Joseph is sold for money; a human being has become a commodity. This is not only a threat to ubuntu, but also to the link with the future. Jacob weeps hearing that Joseph is gone (scene 3), to be sold in Egypt (scene 4). In scene 5 there is trouble in Egypt. In the Bible (Ex 39:10) Joseph refuses Mrs Potiphar's attentions, because submitting to her will be a sin against the Lord. But in the comparable Ancient Egyptian Tale of the Two Brothers ${ }^{17}$ Bata "became like a leopard in his anger over the wicked speech she had made to him... He rebuked her, saying: "Look, you are like a mother to me; and your husband is like a father to me. He who is older than I has raised me. What is this great wrong you said to me? Do not say it to me again!" (Lichtheim 1997: 86). What she proposed would be against the values of the community - in African terms, contra ubuntu! Joseph then interprets the African ruler's dreams (scene 6). In scene 7 Joseph has become a powerful chief in Egypt, but ubuntu is once more threatened when he forces his brothers to leave Simon behind as hostage to go and fetch the young Benjamin. Scene 8 shows how the young Benjamin is sent. Jacob is in tears, the link between past and future (and ubuntu) is at risk of being severed. In the last scene (9) ubuntu is finally restored when the family is unified and tears of joy are shed!

Ubuntu is always at risk, as well as the continuity of the community, which is the link between the past (ancestors and father Jacob) and the future (Joseph and Benjamin). In this way, Mbatha has created a new story, re-telling it in African terms, but also showing that artists are not mere illustrators of a given text, but interpreters in their own right.

\section{John Muafangejo ${ }^{18}$}

John Ndevasia Muafangejo is probably Namibia's most celebrated artist and the first black Namibian who established himself as a gallery artist. He died before Namibia gained independence from South African control. Because of the South African link, his work is included here.

Muafangejo, an Ovambo, was born in 1943 in Okuanyama village in South Angola. In 1956 he went to the missionary schools at Epinga and St Mary's Anglican Mission in Odibo, Northern Namibia, where he was formally trained and demonstrated his artistic talents. In 1967 Bishop Mallory sent him to the famous art school at Rorke's Drift, where he studied until 1969 - one of his teachers was Mbatha. He wanted to study at the University of Cape Town in 1971, ${ }^{19}$ but his application was not successful in spite of the fact that just before that he had represented South Africa at the Sao Paolo Biennale. From 1969 until 1987 he held several successful

17. Translation by M. Lichtheim (1997: 85-89).

18. Cf. Brown (1992), in Eins (1992) and Turner (1996: Vol. 22: 450 with figure). See also the catalogues of Levinson (1992a and 1992b) and Eins (1992).

19. Reflected in the expressive linocut "An interview of Cape Town University in 1971" (Levinson 1992: 60, \#38), with discussion by Timm (in Eins 1997: 7, endnote 3). 
exhibitions and would have received the Guest Artist Award at the Standard Bank Festival of Arts in Grahamstown in 1988, but died of a stroke in 1987. Aged 44, he would have been the youngest artist to have received such an award. In 1992 his complete graphic works appeared under the title I was loneliness (Levinson 1992a).

Muafangejo produced nearly 5800 prints, of which linocuts are the most important medium. Levinson's catalogue (1992a) contains 234 works. Muafangejo regarded his work as educational, with a message that included many symbols that reflect the African mind (Timm in Eins 1997: 5). His work reflects criticism of colonial rule as, for example, in his depiction of the murder of the Ovambo chief Mandume (Levinson 1992a: 61, \#39). ${ }^{20}$ The church influenced his life greatly and he also loved Bible stories. Biblical themes are therefore typical in his work.

In his rendering of Creation (Levinson 1992a: 22, \# 1 and 238, \# $216=$ Fig. 4$)^{21}$ the Creator holds his creation in his hands, but is also present as a mask in the garden. The garden is in African style. According to Lilienthal and Eins (in Eins 1997: 13), Eve is much bigger than Adam, because she has already eaten and she hands over the "forbidden fruit". Both wear the usual leaves. Muafangejo often adds explanatory texts to his art works and here one finds: "As the serpent leers, Eve hands the apple to Adam" (Levinson 1992a: 73, \#51 = Fig. 5). Adam as a patriarch has a beard, whereas the snake is represented quite naturally. On the lower scene "Adam and Eve are expelled from the garden". They are covered by fig leaves and pushed away by an angel in a traditional long white dress. To the left is another figure - a winged being with a sword. Usually in art only one creature with a sword is depicted, but in this case there are two figures, which is closer to Gen 3:24, where there are two ways of protecting the garden: the cherubim and the flaming sword (Cornelius 1997: 228; Von Erffa 1989: 241-242).

As in Mbatha's work, the African context is clearly

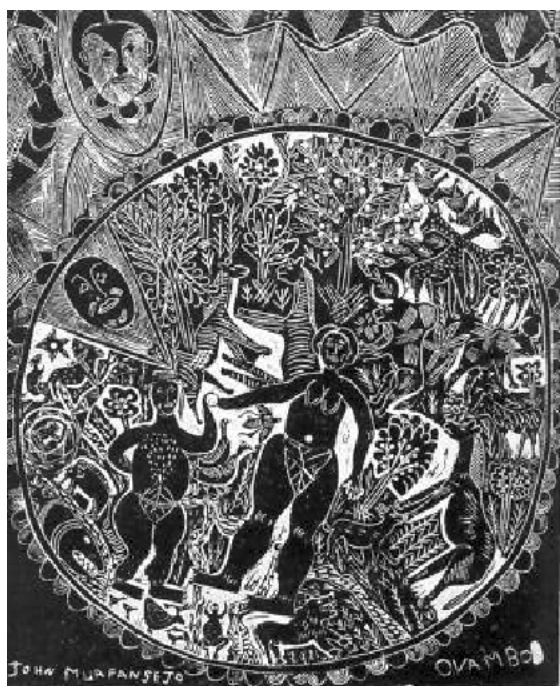

Fig. 4

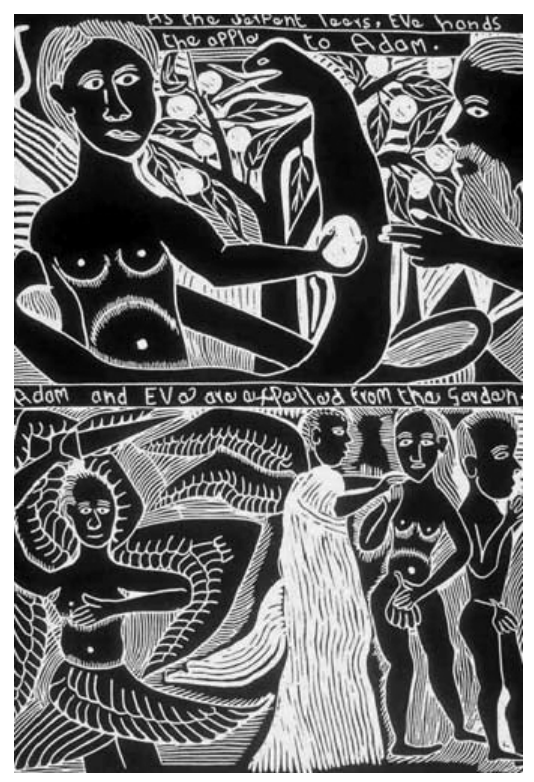

Fig. 5

Fig. 4-5: ( Orde Levinson

20. Discussion by Timm (in Eins 1997: 5-6).

21. This item was first created in 1968 and was called "Adam and Eva" (perhaps due to the influence of Afrikaans and German?) and reproduced in 1985 as "Adam and Eve" (cf. Levinson 1992a: 12). 
reflected in Muafangejo's art. The rendering of the being with the sword and another angel as separate entities is remarkable and unique in art.

\section{Final Remarks}

It has been shown how artists are not only illustrators of a text, but interpreters in their own right. The African context of Mbatha and Muafangejo emerges clearly. In this regard the Joseph story was read as the story of an African family and the concern for ubuntu.

In their book Printmaking in a transforming South Africa, Hobbs and Rankin (1997) emphasise the social role of the print; it served as a form of resistance. The works of Mbatha and Muafangejo are indeed "an iconography of South African society” (Hobbs \& Rankin 1997: 5).

There are many more art works by South African artists that could be included, but this article only wanted to emphasise the point that the repertoire of South African artists should also be included when looking at representations of the Bible in the visual arts!

Addendum: Some years ago I taught a course on the reception of Gen 3. Students undertook various practical projects reflecting on how people read and understand the text. One student did a project on how Stellenbosch students (from all faculties) see the text and asked them to make drawings. The one produced here is anonymous, but the rendering (Fig. 6) speaks for itself!

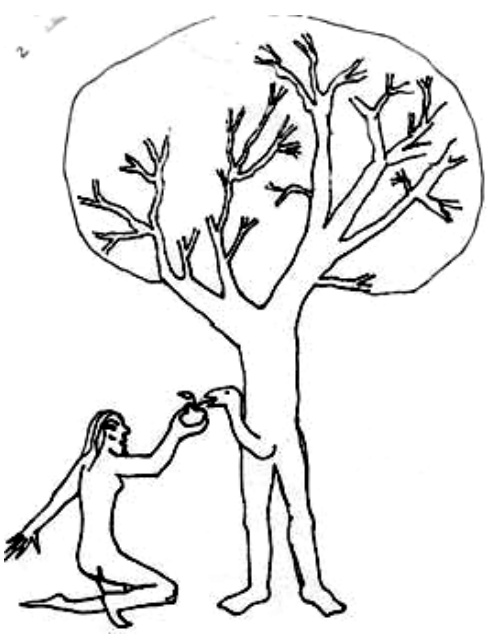




\section{BIBLIOGRAPHY}

Addleson, J et al. 1998. Azaria Mbatha. Retrospective Exhibition, Durban Art Gallery: 14 October to 30 November 1998. Cape Town: South Africa National Gallery.

Adamo, DT 2003. The Historical Development of Old Testament Interpretation in Africa. OTE 16/1, 9-33.

Bocian, M 1989. Lexikon der biblischen Personen. Mit ihrem Fortleben in Judentum, Christentum, Islam, Dichtung, Musik und Kunst. Stuttgart: Kröner.

Brown, A 1992. Muafangejo - Great Linoprint Exponent. Cape Times Saturday April 251992.

Cornelius, I 1997. Some Pages from the Reception History of Genesis 3: The Visual Arts. JNSL 23/2, 221-234.

Eichel, W 1986. Azaria Mbatha. Im Herzen des Tigers/In the Heart of the Tiger. Wuppertal: Peter Hammer/Verlag der Vereinigten Evangelischen Mission.

Eins, A et al. 1997. John Ndevasia Muafangejo (1943-1987):Commemorative Exhibition jubilee programme 1997, Arts Association and National Art Gallery of Namibia. Namibia: National Art Gallery of Namibia.

von Erffa, H 1989/1995. Ikonologie der Genesis. Die christlichen Bildthemen aus dem Alten Testament und ihre Quellen. Bd. 1-2. München/Berlin: Deutscher Kunstverlag.

Gitay, Y 2003. Rhetoric and Its Limitations: Job the Dissident X. JNSL 29/2, 41-63.

Gitay, Z 1993. Ruth and the Women of Bethlehem, in: Feminist Companion to Ruth, 178-190. Sheffield: JSOT Press.

- 1995a. Esther and the Queen's Throne, in: Feminist Companion to Esther, Judith and Susanna, 136-148. Sheffield: Sheffield Academic Press.

- 1995b. The Portrayal of Job's Wife and her Representation in the Visual Arts, in: Fortunate the Eyes that See, 516-526. Grand Rapids: Eerdmans.

Golka, FW 2002. Joseph - biblische Gestalt und literarische Figur: Thomas Manns Beitrag zur Bibelexegese. Stuttgart: Calwer.

Hobbs, P \& Rankin, E 1997. Printmaking in a transforming South Africa. Cape Town \& Johannesburg: David Philip.

Hobbs, P \& Rankin, E 2003. Rorke's Drift. Empowering Prints. Cape Town: Double Storey Books.

Levinson, O (ed.) 1992a. Muafangejo, J.N. I Was Lonelyness. The Complete Graphic Works of John Muafangejo: a Catalogue Raisonné 1968-1987. Cape Town: Struik Winchester.

- 1992b. The African Dream Visions of Love and Sorrow - The Art of John Muafangejo. London: Thames and Hudson.

Lichtheim, M 1997. The Two Brothers (1.40), in: Hallo, WW (ed.). The Context of Scripture. Volume One. Canonical Compositions from the Biblical World, 85-89. Leiden: Brill.

von Rad, G 1976. Das Opfer des Abraham: mit Texten von Luther, Kierkegaard, Kolakowski und Bildern von Rembrandt. München: Kaiser.

van Selms, A 1967. Genesis deel II. Nijkerk: Callenbach.

Sundermeier, T 1977. Südafrikanische Passion. Linolschnitte von Azariah Mbatha. Bielefeld/Wuppertal: Luther-Verlag/Aussaat Verlag.

Turner, J (ed.) 1996. Dictionary of Art. New York: Grove.

West, G 1999. The Academy of the Poor. Towards a Dialogical Reading of the Bible. Sheffield: Academic Press.

- 2001. Mapping African Biblical Interpretation: a Tentative Sketch, in West \& Dube, 29-53.

West, GO \& Dube, MW (eds.) 2001. The Bible in Africa: Transactions, Trajectories and Trends. Leiden: EJ Brill. 